\title{
情報理論とその応用サブソサイエティの成立経緯 と今後の展開に向けて
}

\section{特別 \\ 寄稿}

\author{
New Sub-Society of Information Theory and its Applications: \\ Background and Perspective
}

\section{小林欣吾 Kingo KOBAYASH}

FR 誌編集委員会からの依頼を受けて，基礎・境界ソサイ エティとしての新しい仲間「情報理論とその応用サブソサイ エティ(SITAサブソ)」の成立の経緯と, 今後の研究活動, 研究組織の構成についての期待, 展望について語らせて頂き たいと思います

私が基礎・境界ソサイエティ（ESS）の会長の任にあった ときの, 今を去る 3 年前の2008年7月の頃から, それま でにくすぶり続けていた若手の疑問, 不満をそろそろ解消す べき時期にきていると認識して，電子情報通信学会 (IEICE) とは一線を画して独自の研究活動を展開していた情報理論 とその応用学会 (SITA) のIEICEへの移行の可能性の検討 に入ったのでした。SITAにはSITA将来検討WGが設置さ れ，IEICE 事務局の協力のもと，ESSの活性化WGでも問題 点の整理と検討が行われました。 その後, 2009年に至り, SITAとしての将来の可能な方向の比較検討, SITAがIEICE へ移行した場合の,メリット・デメリットなどが両学会に おいて詳細に，かつ，激烈に議論され，SITAにおいては 2009年 12月の山口・湯田温泉で開催されたシンポジウム 時の理事会, 総会において, SITAが要望する主要な条件を IEICEが受け入れることを条件にして，SITAの解散，IEICE への移行が決議されたのです，それから2010年の 1 年を費 やしてIEICE，SITAの両理事会の了承のもと，IEICE-ESS とSITAのWGとの間で協議が進められ，11月には基本合 意書が締結されました，ここに至るまでに，SITA側では会 長が山本博資氏，藤原融氏と続くもとで多くの役員，会員の 努力がつぎ込まれ，IEICE 側では，会長が宮原秀夫氏，青山 友紀氏，津田俊隆氏と引き継がれる中，ESS 会長として小林 欣吾, 香田徹氏, 松嶋敏泰氏にこの移行事業が受け渡され， 主としてESS 運営委員会配下のWGにおいて検討を重ねて きました

後で述べる事情で，SITA設立当初からこの小学会に打 ち込んでいた者として，SITAの性格からしてIEICEとはと ても相いれないと考えていたのですが，SITA会長も務め，

\footnotetext{
小林欣吾 正員：フェロー 独立行政法人情報通信研究機構

E-mail kingo@nict.go.jp

Kingo KOBAYASHI, Fellow (National Institute of Information and Communications Technology, Koganei-shi, 184-8795 Japan).

電子情報通信学会 基礎・境界ソサイエテ

Fundamentals Review Vol.5 No.1 pp.6-9 2011年7月

C電子情報通信学会 2011
}

IEICE · ESS 情報理論研究専門委員会委員長, ESS会長も 経験してみると，時代は以前とは変化してきており，IEICE の考え方にも柔軟性を見いだせるようになり，また情報通信 研究において情報理論の位置付けにも誤解が生じないまでに 多くの会員の考えが成熟してきたことによって，いろいろな 過去のしこりを解消するべく動く時期が到来したと考えるに 至ったわけです，そもそも，SITAとIEICEの会員とは, 研 究分野を情報理論とその応用を目指す研究者たち (学生会員 は別にして)に限れば, 学生会員を別にすれば, 両学会のど ちらの会員でもあるというものが大半でありました。 なぜ, そのような現象が生じたかは過去の先輩たちの話をたどらね ばならないのですが，その話は別にして，これらの研究者の うちの若手にとっては, なかんずく, 学会を実質的に動かし ている若手にとっては, 二つの学会の雑務を二重に引き受け, 時に一方の学会の立場から意見を言い, また別の学会の役員 の立場から意見を述べなければならないなどということに悩 まされておりました，このことが，若手を研究に集中させる 時間を減少させ，学会活動を懐疑的にさせておりました。一 方, 海外の当該研究分野の研究者たちから見ると，日本のど こに声をかければ適切に同じ分野の研究者たちに呼びかけら れるのか, 日本の対応する代表はどこにいるのかが皆目分か らなくなっていました. このようなふくそうした状態を解消 するため, SITA学会の研究事業をIEICE学会へ移行させる のに適切な時期が到来したと考えたのです，それは，IEICE においても新法人法への法改正に伴い, 組織の見直しも必要 であったし, また, 研究活性化の起爆剂も必要亡思われてい る時期にもあたります. 長らく研究体制を変えてこなかった ESSでも，1999年に発足した非線形サブソ (NOLTA)が, 学会の外で工夫されたシステムによって長い期間にわたって 研究活性化を実現してきたSITAを手本にして, 国際的研究 活動を広げた実績の上に新たにオンラインジャーナルの発行 をしようとする頃でありました。したがって, 活動の形態, 精神が類似のサブソが互いに切磋琢磨して研究を活性化して いく環境が熟成したと見ることもできます。このようなタイ ミングを外しては, また学会の合流という機会もなく, 両学 会の活性化が遅延するであろうという判断がなされた結果の SITAのIEICEへの研究事業継承だと考えています. 分裂を繰り返しがちな学会というものが結集していくとい 
うまれな出来事において望まれることは, 性格の異なる学会 が一つとなることで，それぞれが持っている良い面が強調さ れ，悪い面を洗い流すことです，電子情報通信学会の側から すると, 大学会であるゆえの不自由さで形式的なところにと らわれ，ともすれば権威的な側面が研究の活性化を妨げてい るとすれば，SITAの自由闊達な研究活動のあり方も参考に して改革に取り組むのがいいでしょう. SITA側からすると， 小学会が飲み込まれたという意識で萎縮することなく，小粒 でもぴりりと辛い研究活性化の中核となるべく高い志でこれ までの研究活動を深く進展させていくべきでしょう.

本来, 学会とは研究者の同好会であるべきですが, 組織 が大きくなるとその運営上の問題から規則, 規律が強くな り，時に応じた臨機応変な対応がしにくくなるもので，これ が研究の自由闊達な議論の妨げになることが多い. 現在の電 子情報通信学会には大学会によく見られる極端な弊害はない までも, 非営利型一般社団法人へ移行するという縛りの中で 不自由な考えが混入してきてはいないか顧みることは大切で しょう. それに比べ, 同好会という強い意識で運営されてき たSITAの場合はシンポジウムの形式にしろ, ワークショッ プの運営にしろ, ボランティアの精神が色濃く反映されて, 研究者の自由な思いつきが大切にされてきました．そのよう な学会の原初的形態の良さを大学会の中でも生かせるとした ら, 大学会の四角四面の味気ない大会にも新風を吹き込める のではないだろうか. SITAが電子情報通信学会に参入する ことにより, 学会活動の古くて根源的な形を, 新しい器に盛 り込んでいくきっかけになってほしいものです，

電子情報通信学会の研究の幅, 研究テーマの広がりにはそ の学会名からもおのずから限界が存在します，むやみやたら に何でも取り込むものではありません，一方で，決して手放 してはいけないものがある, その存在の基盤である, 学問 的理論的な支えをなす研究分野は堅持しなければいけませ ん. その過ちをなして, 世界の情報通信の理論的研究のすう 勢から置き去りにされたという苦い経験をIEICE は持ってい ます，そのことを憂えて，日本における情報通信の理論的研 究の地ならしをしてきたのがSITAなのです．この小学会は IEEE のISIT (International Symposium on Information Theory）を2回日本において開催する中心的役割を果たし， 二人のシャノン賞受賞者を輩出するほどに実力をつけてきま した．これは，学会の形態にとらわれず，本質的に重要な意 味を情報通信研究に求める姿勢が貫かれていたからに他なり ません，電子情報通信学会の外で十分成長したこのグループ は, 電子情報通信学会の理論的中核となるために舞い戻った と考えるべきだと思います．

今の若い研究者には余り実感の湧かない苦い経験とは, 次のようなことでした，戦後間もなくの1948年にシャ ノンによって著された"The Mathematical Theory of Communication” は通信の画期的理論としてその頃学問に 飢えていた日本の俊英たちに受け入れられ集中的に吸収され たのです，そして思いの外素早く，電気通信学会において も1952年にインフォメーションセオリイ研究専門委員会
(IT研専)が作られたのです，しかるに，1960年代も半ば になると日本では熱も泠め, 私が学部学生の頃の, 少ない情 報理論のある教科書の冒頭には,「すでにこの分野は「dead field」であるという意見もあるが, 未解決な問題も多く, 他 の専門分野との関連において飛躍的な発展が期待される」と いう, 学生にしてみると, もう既に終わってしまった学問で あるというのが一般の見方であるかのような印象を与える文 言さえ見られていたのです，その挙げ句，1966年にはけ研 専は解散. 通信方式, 医用電子, オートマトンなどに吸収さ れ，1972年の大改組の際には, 時の流行に乗ったパターン 認識, 学習理論, オートマトンなどが残る中, ついにけの名 残はなくなりました，海外では，1960年代は情報理論の地 道な土台が形成されていた時期にあたり，その蓄積された研 究パワーが, 1970年代に入って衛星通信, 深宇宙通信など の最先端の研究を支える多端子情報理論 (現在はマルチユー ザ情報理論とも称せられている）として一気に開花したので す.このような状況の中、1 1977 年有本卓先生、杉山康夫氏 (1987 年逝去) が、米国Ithacaのコーネル大学で開催され たIEEEのISITに出席され、海外の情報理論研究の活況を目 のあたりにして, 日本のこの分野の出遅れに大きな危機感を 抱かれました. 帰国後, 直ちに行動を起こし有志を集結して, 1978年 11 月神戸において, 当時手続きの煩雑な電子通信 学会(IECE) とは別の機動性豊かな手作りのシンポジウムの 開催にこぎ着けたのです，その成功に刺激を受けて 1981 年 に至り，IECEには情報理論研究專門委員会が復活し，その 後, ESS の情報通信基礎サブソの一員として研究会活動を 続けて, 今年からは情報理論とその応用サブソに所属してい ます.一方, 同好会として出発したSITAは1986年に学会 としての体制を固め, 1988 年に神戸においてIEEEのISIT を招請する中心的役割を担ったのでした，もちろん，このと きの成功にはIEICEの協力が大切な要素でもありました，実 は，1978年のSITA立ち上げはこのISIT1988Kobeを目 標に仕組まれた 10 年に及ぶ大仕掛けだったのです，その中 心人物の一人，杉山康夫氏の前年の逝去は何とも悔やまれる 出来事でありました，その後，やはりIEICEの大きな支援を 得て協同して2003年に再度ISITを横浜に招請し，大きな 成功を収めたのでした，とはいえ，SITA設立当初は後何年 持つのかも分からない中, 毎年充実したシンポジウムのお陰 で一度でも参加したものは病み付きになるということで年々 会員は増えていきました. しかし，はじめの頃のナイトセッ ションでは酒を飲み交わしながら，情報理論は役に立つの か? という議論が随分長い間続いていました。 今でこそ，そ んなことを問題にする研究者がいたら何と不勉強で見識がな いと思われるでしょうが, その頃は海外の動向も知らず井の 中の蛙のごとき, 研究者が一杯いたのです. また, 理論の適 用範囲も理解しないで夢想にふけったり, 数学的な厳密さで 証明されている理論的限界の意味をはき違えて, シャノン理 論を超えたなどと放言する御仁もいたりで，互いにたしなめ 合ったものです．1986年の学会化においても，学会化する ことにより同好の士の集まりが崩れて権威主義的, 事務的傾 
向が強まりはしないかという危惧が多く語られました。しか し, 会員の高いボランティア精神のお陰で, シンポジウムだ けでなく適切な時期に，魅惑的なテーマで少人数によるワー クショップなどが持続的に実施され，SITA設立当時の初志 は綿々と受け継がれてきました，その精神はSITAがIEICE に合流したとしても失われることはないというメンバーの了 解は行き渡っていると考えています。

以上のような経緯をたどって，ある意味で，情報理論とそ の応用に関する研究分野を束ねる日本の唯一のグループとなっ たSITAサブソには, 設立時の初心を堅持し，国内シンポジウ ムSITA，国際シンポジウムISITAの更なる充実を図り，また テーマを限ったワークショップをタイムリーに行うことが求 められます、今や、海外，国内を問わす随分と会議が多いの で消化不良を起こさない心掛けもまた必要でしょう，研究の時 間を十分取った上での，満を持した発表というものが研究活性 化のあかしなのです，論文の盗作，コピペはあってはならない ことですが, 現在のようなせわしい研究環境では, 論文の洪 水の中でアイデアのコピペが本人にも意識されないままなさ れることもよくあります．こんな時代だからこそ，拙くても 自分の頭でこんこんと考えた個性ある思考に価值を求める研 究グループとなっていくべきでしょう. 以前のSITAであれば ジャーナルを持たないということが一つの信念でしたが, 今 やオンラインジャーナル (既にNOLTAが実施している) であ れば年2回あるいは4回くらいなら，質の高い論文を扱うこ とができるでしょう. それに向けての検討に入ってもいいか と考えます，ただし，海外の一流誌でrejectされた，あるい は, rejectが予想されるような質の低い論文の掃きだめとな るようなジャーナルにならないように注意する必要がありま す.そのためには, NOLTAの行っているように海外からも実 力と見識を備えた研究者(会員でなくとも構わない)に查読を 依頼し，無闇に発行部数は増やさないことです。ここに採択 された論文に高い価值を認められるようにしましょう. シャ ノンもBandwagon (IRE Transactions, IT, vol.2, no. 1, p.3, 1956) で「Authors should submit only their best efforts, and these only after careful criticism by themselves and their colleagues. A few first rate research papers are preferable to a large number that are poorly conceived or half-finished.」と言ってます. 最近, ESSの論文誌体制検 討WGにおいて進められている，これまでの和文論文誌·英文 論文誌のあり方を見直す作業にも，上記のような考え方を，出 版される論文の価値を高めるために反映することが望まれま す.

ふくそうした構造を単純化して生まれたSITAサブソの活 動を意味あるものにするにあたつて，心して頂きたいことを 列挙すれば,

（1）これまでのような二つの学会の雑事に追い回されかね なかった若手が、気を散らすことなく研究に集中出来 る時間が確保されるように信頼性, 透明性のあるもの にすること

（2）日本における情報通信の理論的研究の母体が，外国か
ら見て明らかになっていること. 日本であれば,ここ に声をかければこの分野の代表するメンバーはすべて そろっているという形が望ましい，ある分野に関連す る学会などが幾つか存在し, それぞれが縄張りを主張 しあっているというょうな姿を近隣諸国だけでなく, 日本の中にもよく見ることができます，そのような見 苦しい姿に陥らないようにしたいものです，

(3) 形式に縛られない. 先輩, 後輩の垣根がなく, 研究者 としてメンバーは全て対等という気風がみなぎるよう に. シンポジウム, ワークショツプの性格を決める大 切な鍵です. 一部の役員だけがサブソの運営に責任を 持つというのではなく，構成員が皆がそれぞれの意見 を持ち寄り，発言ができる場を確保することは重要で しょう.

(4) 国際的視野の涵養を進め, 学会に縛られない研究者の ネットワークの構築を目指すこと，例えば，IEEEのIT Societyは, IEEEの会員でなくとも, その研究分野に おいて優れた業績を示した研究者にはシャノン賞や論 文賞を授けるのにためらうことはない，学会という枠 を越えて研究を評価することのできる大きな視野と寛 容さを備えねばならない，電子情報通信学会はこれま で自分のJournalに揭載された論文だけしか賞の対象 とは見てこなかった，難しいことだが，優れたものを 正しく評価できてこその国際化ではないだろうか，そ のような柔軟な包容力のある思想をSITAサブソでは 大切にし, 学会全体の気風にまで高めよう. 権威主義 を排し, 小回り, 機動性, 柔軟性, ボランティア精神 を重んずる研究グループとなるべきであろう.

(5) サブソを構成するメンバーのためには，これまでと同 様にNews Letterの発行を継続すること. SITAが IEICE-ESSにサブソとして参入し，その研究事業を継 承していくにあたって, News Letterの発行を中止し ていますが, これまでのSITAの大切な財産でもある 過去のNews Letterのバックナンバーを継承するの は，SITAの初心を受け継いでいく意思の表れでもあ り，SITAサブソのNews Letterとして再生させてほ しい，会員各位に広く知ってもらいたい意見・情報で あれば, ESSのFR誌にサブソのニュースを掲載すれ ばいいという考えがありますが, サブソに特有な研究, 若手の博士論文解説, サブソのメンバーに特に訴えた い意見などはNews Letter掲載が向いています. FR 誌は，ESS全体に係る横断的な二ユース，記事に専念 すべきでしょう.このNews Letterはこれまでと同様, 関心のある人なら誰でも読むことができるようにすれ ばいいし，FR誌からリンクを張っておくのもいいで しょう.このような性格のNews LetterはESSの他 のどのサブソでも持つことが望ましいと思います，そ れらは他のサブソの活動を互いに理解しやすくし, 閉 鎖性を打破することにもつながります

（6）4ソサイエティ制度の改革を進めることにより, 電子 
情報通信学会に新しい風を起こそう.ソサイエティ制 への移行時における判断の混乱の中で, 基礎・境界ソ サイエティはサブソシステムという他のソサイエティ とは異なる形態を選んでしまいました。こてれには, 学 会を分割して独立採算を目指すという意図から, 各ソ サイエティができるだけ同等の規模であるのが望まし いということを優先したからなのだと思われます，独 立採算を目指す単位としての発想が等分割案につなが る不自然さに当時はおかしいと気付かなかったのは無 理もなかったかもしれませんが, 今やそのようなこと にとらわれず, 定期的な国内，国際シンポジウムを行 い, いずれ電子Journal を出していける見込みのある, 学問としての理念, 意思の確固とした国際的に認知さ れているグループにはソサイエティとしての資格, 活 動を与えることは妥当なことです。ソサイエティを名 乗ることにより，サブソの枠組内，あるいはグループ の名のもとに国内的に閉じ込もって，国際的視点を持 たない內向きの雾囲気を温存しためるま湯から脱出す る好機にするべきなのではないでしょうか，IEEEでも そうだが, 各ソサイエティは粒度は違っていても構わ ないはずです、現在, 学会は長らく4ソサイエティ 1 グループとなったままですし，最近は，新法人法への 移行対応に追われたりして, 学会全体の大きな改革が 目指されていないように思います，殊にESSは一つの 研究理念ではくくれない幾つもの研究グループが, サ ブソサイエティ, あるいは, ぞこにも属さない研究專 門委員会として長い年月変化することなく，互いに余 り影響を及ぼすこともなく分散して存在してきました. そこに，変化の兆しが認められるようになってきてい ます．すなわち，ESSの成立時には存在していなかっ たNOLTAサブソがオンラインジャーナルを発行でき るまでに成長し，それに同期して，新たなサブソSITA がESSに生まれることとなりました，この変化を， ESSの各サブソがソサイエティへの発展につなげるこ とにより, 従来の4ソサイエティ1グループの構造に 变革を加え, 学会全体の活性化を図りたいものです。

一つの学会が消滅し, 研究グループの整理が行われたとい うこのまれな出来事に際して, 良き伝統を保持し, 新しい命 を吹き込むために，上に掲げた六つの項目の視点を失わすに， 今後の学会活動の指針となってほしいと思います。

最後に, 電子情報通信学会が現社団法人から非営利型一般 社団法人に生まれ変わる大变な時期にも関わらず, 研究に対 する価値観を共有する研究集団が結束して一つにまとまり， 国際的にも認識されるグループを形成することの重要性を認 識して, SITAのIEICE-ESSのSITAサブソへの研究事業継 承を全面的に支持して頂いた歴代の理事会, 会長並びに事務 局に感謝申し上げます。

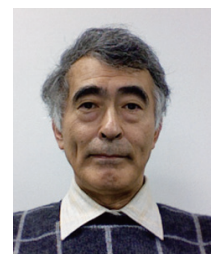

小林欣吾 (正員 : フェロー)

昭 45 東大大学院工学系研究科修士課程了. 昭 45

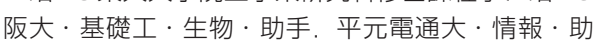
教授。平6同教授，平 11 同情報通信工学科教授，平 21 独立行政法人情報通信研究機構上席研究員. 平 23 同R\&Dアドバイザー。この間, 米国・コーネ ル大客員研究員, ドイツ・ビーレフェルト大客員教 授, 名大, 九大, 電通大非常勤講師を歴任し, 情報 理論, 離散情報構造の研究に従事. SITA会長 (平 16 ～17). 工博. IEEE Fellow. IEEE IT Associate Editor on Shannon Theory (2004 2007), 本 学会IT研究専門委員会委員長 (平 12), 基礎·境界ソ サイエティ会長 (平20), 基礎・境界ソサイエティ編 集長(平21)などを歴任. 